\title{
Introduction
}

This text and translation of the month of June is the sixth volume of our projected twelve-volume text and English translation of the Armenian liturgical book known to Armenians as the Yaysmawurk: To the Orthodox it is called the Synaxarion or sometimes Menologion, and to westerners, especially Roman Catholics, it is generally known as the Martyrology. In our first volume, that of January, one can find a brief, introductory discussion of the history and primary versions of the Yaysmawurk' and its historical place in the worship of the Armenian Church. ${ }^{1}$

\section{A Note on the Text and Translation}

As already noted in previous volumes, Bayan's edition of the Yaysmawurk', which we have been using as the text for our translation, is actually a compilation of two different versions. In addition to reproducing his base text, Bayan also reproduced selected texts from his B version without any editing. More often than not these texts were added as they celebrated saints or martyrs not included in his base text, but sometimes these texts were simply fuller, or more embellished texts that he included as additional witness. Examples of both also sometimes fell on different days from those found in his base text.

For this month of June, however, the text runs rather smoothly; there are no duplicate versions, only several additional entries that I have simply incorporated from Bayan's manuscript B into our

1. Mathews, On This Day: The Armenian Church Synaxarion-January, xvii-xx, although the history is far more complicated than that introductory discussion suggests. A summary account of its contents can be found in Zanetti, "Apophthegmes et histoires édifiantes dans le synaxaire arménien”. 
translation as if they were part of the original. I have utilized no specific markers to indicate these additional entries, but have simply employed continuously running paragraph numbers. I am aware that this projects a false unity to the translation, but I hope that this will matter little to the intended audience.

\section{Further Acknowledgments}

As with all previous volumes, I offer my most profound thanks to my dear friend and colleague Anoushavan Srpazan Tanielian who has once again found enough time to read carefully through my entire text and translation and-as he has always done-saved me from numerous errors and infelicities. He continues to amaze me with both his industry and his generosity.

I have been responsible for inputting the Armenian text in all these volumes to date, but for this volume I wish to offer my sincerest thanks to Cathy, Tom and Laurie, not for typing in the text for me but for providing me the peace, quiet and stability in order for me to carry out this task at a time when those things had been temporarily taken away from me. Their friendship, their sacrifice, their hospitality, their love, and their generosity of spirit will remain with me forever. May the Good God and all His Saints bless them now and always! 
ON THIS DaY

JUNE 


\title{
Uшptph h6
}

\author{
3nıLpup U.
}

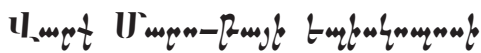

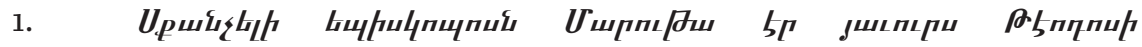

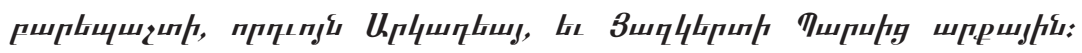

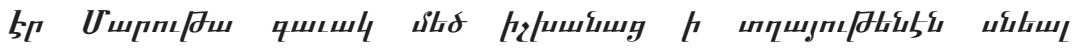

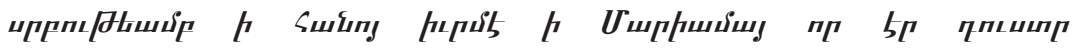

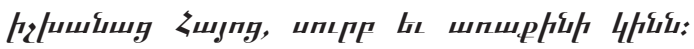

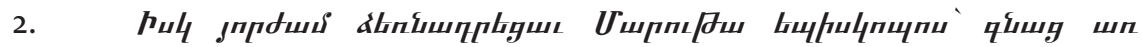

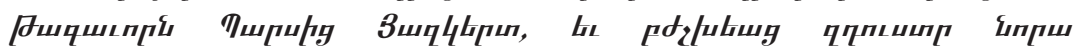

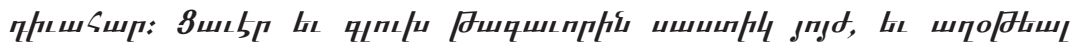

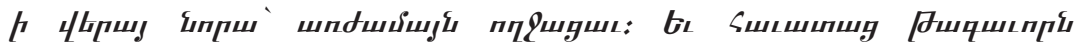

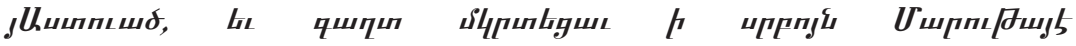

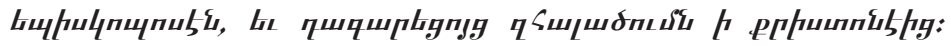

